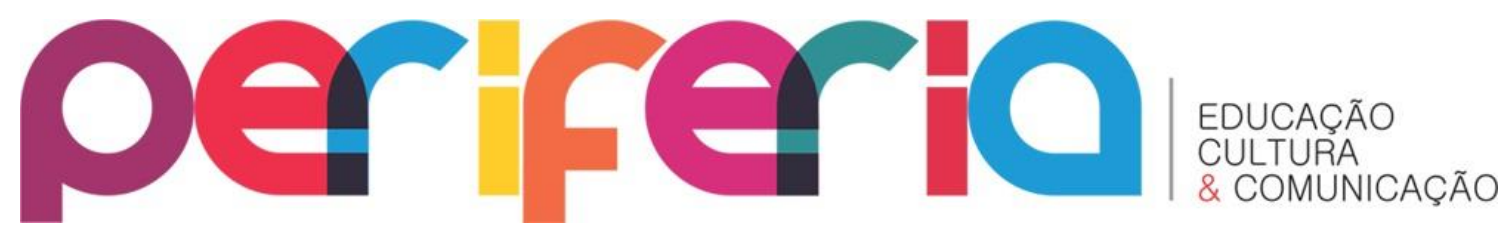

\title{
A CORRERIA COMO FORMA DE RESISTÊNCIA NEGRA EM VIDEOCLIPES DO RAP BRASILEIRO
}

\author{
Solange Stéfane Santos ${ }^{1}$ \\ Cláudio Coração
}

\section{Resumo}

O presente artigo analisa a produção dos videoclipes "Crime Bárbaro", de Rincon Sapiência, "Corra", de Djonga e o curta "Bluesman", de Baco Exu do Blues, almejando compreender como tais artistas aliam os conceitos de identidade e resistência ao ato de fuga, caracterizado nos clipes pela corrida contínua empreendida pelos personagens principais. Busca-se também investigar como suas narrativas ajudam o espectador a compreender a correlação entre o racismo estrutural e o genocídio de jovens negros no Brasil. Por fim, intui-se estabelecer se o ato de correr empreendido nas narrativas ficcionais do videoclipe pode ser caracterizado através de uma perspectiva estética em torno de fronteiras e frestas culturais.

Palavras-chave: correria, videoclipes, genocídio negro, rap.

\section{THE RUSH AS A FORM OF BLACK RESISTANCE IN BRAZILIAN RAP}

MUSIC VIDEOS

\section{Abstract}

This article analyzes the production of the video clips "Crime Bárbaro", by Rincon Sapiência, "Corra", by Djonga and the short film "Bluesman", by Baco Exu do Blues, aiming to understand how such artists combine the concepts of identity and resistance to the act of escaping, characterized in the clips by a continuous race undertaken by the main characters. It also seeks to investigate how their narratives help the viewer to understand the correlation between

\footnotetext{
${ }^{1}$ Bacharel em Publicidade e Propaganda pela Pontifícia Universidade Católica de Minas Gerais (2018). Mestranda no Programa de Pós Graduação em Comunicação pela Universidade Federal de Ouro Preto (2019). Bolsista CAPES. E-mail: solstefane@gmail.com. ORCID iD: https: / /orcid.org/0000-0002-6122-0491.

2 Professor do Programa de Pós-Graduação em Comunicação e do curso de Jornalismo da Universidade Federal de Ouro Preto (UFOP). Doutor em Comunicação: meios e processos audiovisuais pela ECA/USP. Coordenador do Grupo de Pesquisa 'Quintais: cultura da mídia, arte e política' (CNPq-UFOP). E-mail: crcorao@gmail.com. ORCID iD: https://orcid.org/0000-00021402-7787.
} 


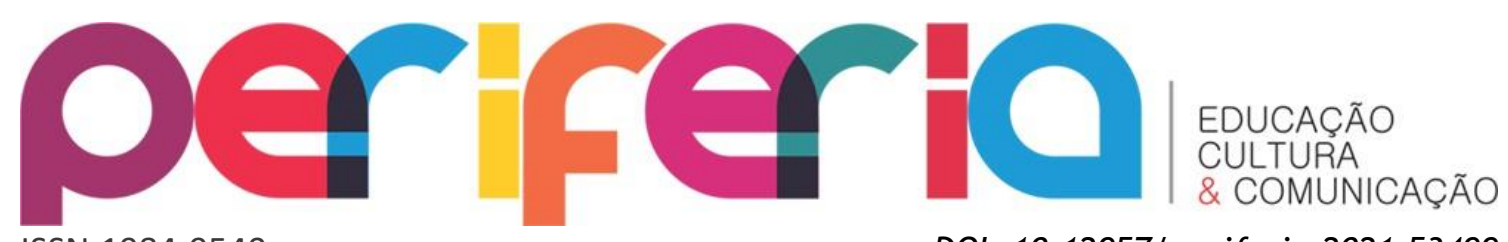

ISSN:1984-9540

DOI: 10.12957/periferia.2021.53499

structural racism and the genocide of young blacks in Brazil. Finally, we intend to establish whether the act of running undertaken in the fictional narratives of the video clip can be characterized through an aesthetic perspective around cultural cracks and boundaries.

Keywords: rush, video clips, black genocide, rap.

\section{LA PRISA COMO FORMA DE RESISTENCIA NEGRA EN LOS VIDEOS MUSICALES DE RAP BRASILEÑO}

\section{Resumen}

Este artículo analiza la producción de los videoclips "Crime Bárbaro", de Rincon Sapiência, "Corra", de Djonga y el cortometraje "Bluesman", de Baco Exu do Blues, con el objetivo de comprender como estos artistas combinan los conceptos de identidad y resistencia al acto escape, caracterizado en los clips por la carrera continua realizada por los personajes principales. También busca investigar cómo sus narraciones ayudan al espectador a comprender la correlación entre el racismo estructural y el genocidio de jóvenes negros en Brasil. Finalmente, tenemos la intención de establecer si el acto de correr emprendido en las narrativas ficticias del video clip puede caracterizarse a través de una perspectiva estética en torno a los límites culturales y las grietas.

Palabras-clave: correr, videoclips, genocidio negro, rap.

Introdução: Por que branco correndo é atleta e preto é ladrão?

Correr é verbo intransitivo na Língua Portuguesa e corresponde à ação de imprimir grande velocidade contra o solo, pelo contato rápido dos pés ou patas (MICHAELIS, 2020). Tal ação é executada pelo ser humano como forma de chegar do ponto $A$ ao ponto $B$, por motivos diversos, como o exercício ou a fuga. Voltando nossos olhares para a fuga esta pode ser desencadeada, por exemplo, pelas ações efetivadas pelo aparato policial, que, ao entrar nas favelas, acarreta o desarranjo das ações instituídas no local, como foi o caso ocorrido na favela de Paraisópolis, na qual uma correria desordenada causada pela ação da polícia levou a morte de nove jovens em um baile funk ${ }^{3}$.

3 . VEJA, Revista. Veja quem são os nove jovens mortos na favela de Paraisópolis: Vítimas de tumulto ocorrido após ação da PM em um baile funk tinham entre 14 e 23 anos. Revista Veja, 


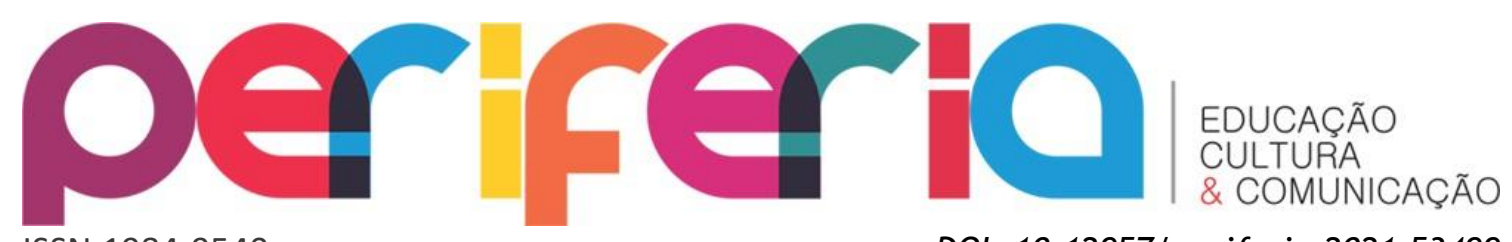

ISSN:1984-9540

DOI: $10.12957 /$ periferia.2021.53499

As favelas existentes no Brasil atuam como uma espécie de fragmento do período pós-escravidão, uma vez que os negros excluídos da sociedade migravam para as regiões dos campos e morros e ali construíam barracos, que se proliferaram e se tornaram a única moradia possível para os grupos socialmente marginalizados, de forma que, segundo Carmo (2017), a pobreza nunca foi somente uma questão de classe, uma vez que gênero e raça também estavam envolvidos. Conforme apresentado pela autora, ao confrontar dados do IBGE de 2014, foi evidenciado que $76 \%$ da população mais pobre do Brasil era formada por negros e que $70 \%$ dos moradores de favela, somente em São Paulo, também pretos e pardos.

A marginalização e a falta de representatividade desta população reforçam os ideais ligados a criminalidade e a falta de instrução, visto que jovens negros entre 15-29 anos são as maiores vítimas de homicídio no país, representando cerca de quatro em cada cinco das vítimas, o que nos últimos 20 anos caracterizou um aumento de $429 \%$ de mortes de jovens, ante $102 \%$ de mortes contra jovens não brancos (PUTTI, 2019).

Mediante tal cenário, o presente artigo visa analisar três videoclipes propostos por jovens cantores negros, sendo eles: "Corra" de Djonga, "Crime Bárbaro" de Rincon Sapiência e "Bluesman" de Baco Exu do Blues. Neles é colocado em plano central o negro que corre da polícia, da morte ou até mesmo para o encontro com amigos e familiares.

Nosso objetivo é observar como os jovens cantores abordam a questão do genocídio negro contemporâneo, bem como aliam o ato de correr a uma atitude de resistência. Por fim, buscaremos analisar se a partir da análise de tais videoclipes, podemos estabelecer a existência de uma estética da correria $^{4}$, e, se sim, responder como esta ocorre dentro do cenário imagético do videoclipe.

[S. l.], 2 dez. 2019. Disponível em: https://veja.abril.com.br/brasil/veja-quem-sao-os-novejovens-mortos-na-favela-de-paraisopolis/. Acesso em: 6 jan. 2020.

4. O termo correria será empreendido neste trabalho como ato de fuga, não devendo ser confundida com as ações empreendidas para o massacre de índios no Acre nos séculos XIX e XX ou ainda com a gíria utilizada por detentos para atribuir suas relações com o tráfico de drogas. Para compreender melhor a correria enquanto ato de eliminação de povos indígenas, indica-se 


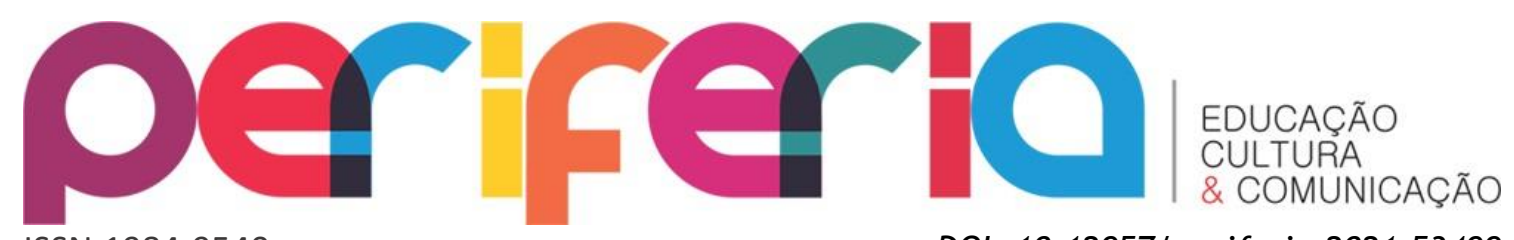

ISSN:1984-9540

DOI: $10.12957 /$ periferia.2021.53499

Considerações Iniciais: Deuses presos em casulos, correria como resistência.

As narrativas nas quais escravos tornam-se homens livres não são poucas, embaladas ou não por uma aura fictícia a noção de sofrimento é afligida aos afrodescendentes de alguma maneira. Podemos recordar a narrativa de Django Livre (Django Unchained, 2012), cujo o Django Freeman (Jamie Foxx), um exescravo, trava a aliança com um homem branco, Dr.Schultz (Christoph Waltz), a fim de resgatar Broomhilda (Kerry Washington), sua esposa de um fazendeiro (Leonardo DiCaprio), que obriga seus escravos a travarem lutas mortais. Embalado por um ideal cinematográfico digno de Tarantino, a narrativa conta com uma violência visceral e sangue por todos os lados. 0 que nos leva a questionar se mais sofrimento é necessário para contar sobre este período histórico tão doloroso para aqueles que foram fortemente brutalizados.

Fugindo da narrativa ficcional dos filmes hollywoodianos, estima-se que entre os anos de 1500 e 1856 quatro milhões de escravos chegaram ao litoral brasileiro e trezentos mil morreram a caminho do Rio de Janeiro, vindos sobretudo da Angola e do Congo, estes foram importados para o trabalho nas lavouras de café (FRANÇA, 2015).

Os escravos eram tratados socialmente como fantasmas, uma vez que sua cultura, hábitos e organizações sociais eram suprimidas e em contrapartida a esses não era ofertada uma entrada ativa na sociedade, sendo-lhes negada a participação em missas ao lado de seus senhores, bem como da educação formal ofertada por padres, de modo que a obrigatoriedade do batismo era meramente formal, por não existir parte da igreja qualquer interesse para uma efetiva conversão (BORGES, 2017).

Entretanto, esta realidade não era aceita de forma passiva, conforme se possa pensar, agrupamentos de escravos fugitivos ocorreram em todos os locais onde houve escravidão e no Brasil estes agrupamentos foram chamados de quilombos ou mocambos e, por diversas vezes, conseguiam agrupar milhares de

a leitura da dissertação de Ernesto Martinez Rodrigues, intitulada "Correrias: Índios, Gaucheiros e Seringueiros" (Acre 1942/1983). 


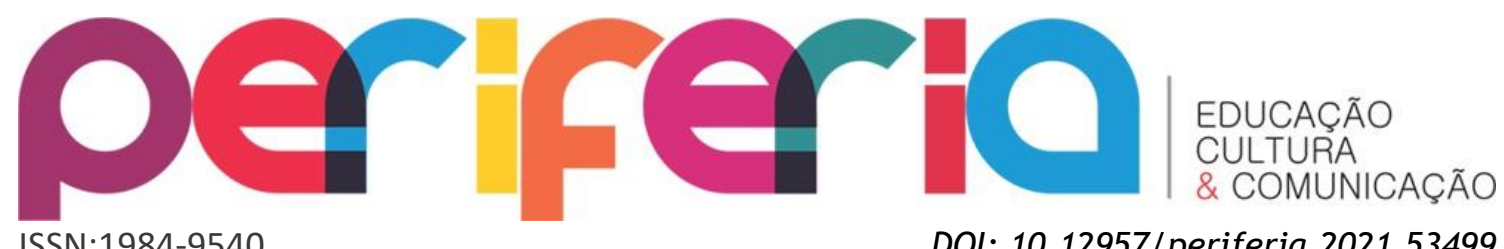

pessoas, por serem constituídos por escravos fugidos e seus descendentes, bem como índios, soldados desertores, perseguidos pela justiça secular e eclesiásticas, vendedores ou simples aventureiros. Esses agrupamentos se formavam através de adesões individuais e/ou coletivas de escravos fugitivos, ou eram resultado de revoltas, como parece ter sido o caso de Palmares.

O próprio termo quilombo derivaria de kilombo, uma sociedade iniciática de jovens guerreiros mbundu adotada pelos invasores jaga (ou imbangala), estes formados por gente de vários grupos étnicos desenraizada de suas comunidades. Esta instituição teria sido reinventada, embora não inteiramente reproduzida, pelos palmarinos para enfrentar um problema semelhante, de perda de raízes, deste lado do Atlântico. Teria sido de fato depois de Palmares que o termo quilombo se consagrou como definição de reduto de escravo fugido (REIS, 1995/96, p. 16).

Por não atuar como uma cultura monolítica, africanos de diferentes etnias e culturas habitavam o quilombo e necessitavam administrar suas diferenças e criar laços de solidariedade, para que a manutenção de tais assentamentos fosse possível.

Cento e trinta anos se passaram desde a assinatura da Lei Áurea, tal documento foi responsável pela abolição da escravatura no país e consequente liberação do povo negro cativo aos senhores de engenho, e, no entanto, a situação desta parcela da população pouco se modificou, de forma que a cultura da supremacia branca ${ }^{5}$ continua a guiar o pensamento contemporâneo, e o assassinato de jovens negros já levanta discussões sobre um possível genocídio negro no Brasil (MARQUES, 2017).

O lançamento de produtos culturais que denunciam o racismo sofrido por moradores de periferia, negros ou não negros, não é algo novo no mundo do rap. No Brasil, a criação dos Racionais Mc's em 1988 foi essencial para que a denúncia da violência policial e do desamparo dos moradores da periferia de São Paulo chegasse a grande mídia (TEPERMAN, 2015). Entretanto, a noção de uma cultura negra de resistência é algo relativamente novo, segundo hooks

\footnotetext{
${ }^{5}$. Termo utilizado por bell hooks (2019), para referir-se às circunstâncias relacionadas à ideologia racista e ao colonialismo, em que as narrativas culturais e a produção de conhecimento partem do ponto de vista de pessoas brancas. 0 que não deve ser, portanto, confundido com os ideais de pureza racial.
} 


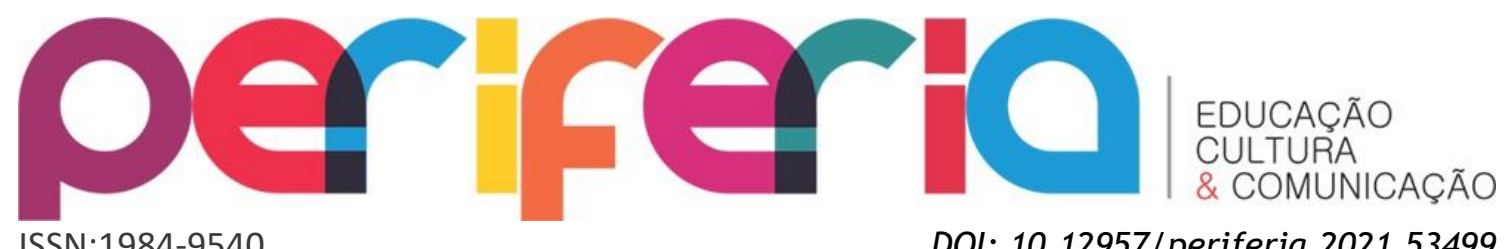

(2019), tendo surgindo no contexto do apartheid e da segregação ${ }^{6}$, o que abriu espaço para o tipo de descolonização que torna possível o amor à negritude. No entanto, a manutenção social do pensamento racista continua a relegar os negros a um local de não existência e auto-ódio.

A chegada de produtos culturais como o rap de Childish Gambino, em 2018, com “This is América” nos Estados Unidos e "Crime Bárbaro" de Rincon Sapiência no Brasil, demonstram que, cada vez mais, surge por parte da juventude o desejo de se discutir sobre o racismo na sociedade.

Isso vem de uma construção histórica e tem a ver com uma
tomada de consciência cada vez maior, principalmente por
parte da juventude, de que ser negro não é uma coisa ruim. As
pessoas negras estão revertendo isso internamente e também
colocando para fora, construindo contra narrativas frente a uma
sociedade que as diz o contrário. (BUZATTI apud COSTA, 2018).

O lançamento do videoclipe de "Crime Bárbaro" de Rincon Sapiência ocorreu em 13 de maio de 2018, dia em que é comemorado a Abolição da Escravatura, no Brasil. Galanga é personagem fictício que empreende a própria fuga após matar o senhor de engenho. A data de lançamento foi escolhida propositalmente, uma vez que confronta o ideal da libertação atrelado a abolição por parte de uma princesa branca. A crítica a datas comemorativas tais como a da abolição pode ser compreendida através do pensamento de hooks (2019), que alega que a existência de rituais de afirmação, tais como a celebração da história dos negros, feriados e slogans como Black is Beautiful têm pouco ou nenhum efeito quando pensados fora de uma luta antirracista que atue de forma ativa para a transformação da sociedade, já que sem uma luta de resistência eficaz pessoas negras continuarão a ser socializadas seguindo ideais concernentes a supremacia branca.

\footnotetext{
${ }^{6}$. 0 apartheid refere-se a um sistema constitucional de segregação racial que abrangeu todas as esferas sociais, econômicas e políticas na África do Sul, por meio das ações praticadas pelo Partido dos Nacionalistas que ascendeu ao poder em 1948. Disponível em: <https://educacao.uol.com.br/disciplinas/sociologia/apartheid-auge-e-declinio-do-regimedo-apartheid-sul-africano.htm>, acesso em: 14 de jan de 2020.
} 


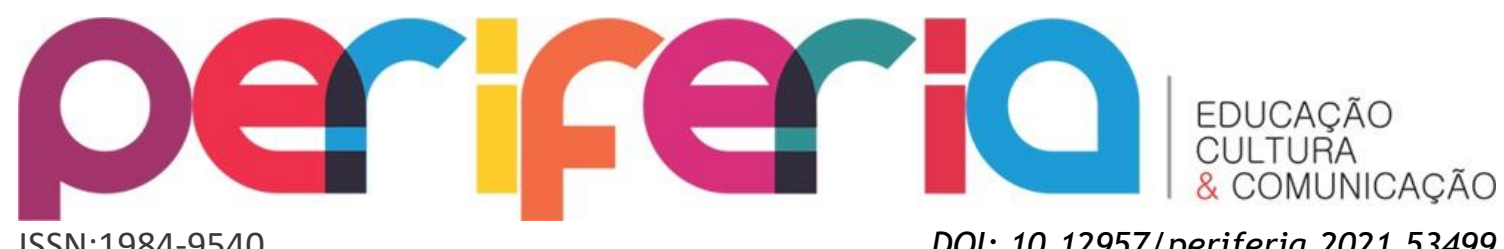

ISSN:1984-9540

DOI: 10.12957/periferia.2021.53499

Galanga é apresentado em fuga em meio a um cenário escuro, o que leva o leitor da obra a não compreender se este foge ao longo da noite ou para onde foge e ao correr é perseguido por um policial, que encarna a figura do capitão do mato.

Capangas armados estão à procura Escravos apoiam meu ato de loucura

Fugido eu tô correndo pela mata Na pele eu levo a marca da tortura 0 crime deixa doido o bagulho Carrego um pouco de medo e orgulho Atrás da orelha deles eu sou a pulga Se eles chegar tô pronto pra dar fuga Por mim estaria tudo em paz Minha terra, meu povo e ninguém mais Liberdade por aqui ninguém traz Sim senhor, não senhor, não satisfaz Arrependimento, isso eu não tenho O meu movimento sempre mantenho

Escravos apoiam meu desempenho Foi eu que matei o senhor de engenho. (RINCON SAPIÊNCIA - Crime Bárbaro, 2018).

Tal figura repressora atuava como uma milícia especializada na caça dos escravos fugidos e na destruição dos quilombos e foi criada como forma de atribuir estratégias repressivas para a supressão da formação de mocambos. Compreender as atitudes dos capitães do mato nos ajuda a compreender o ato de fuga de Galanga, tomando a exemplo Minas Gerais no começo do século XVIII podemos compreender por que a metrópole de Portugal buscou tornar as torturas mais brandas.

Em Minas Gerais, durante a primeira metade do século XVIII, autoridades locais e os próprios governadores, atormentados com a proliferação dos mocambos, conceberam punições bárbaras contra os quilombolas, como cortar-lhes uma das pernas ou o tendão de Aquiles. Foi a metrópole que controlou a sanha dos mineiros, recomendando a barbaridade menor de imprimir com ferro em brasa a letra "F" sobre a espádua do fujão e o corte de uma orelha no caso de reincidência (REIS, 1995/96, p. 20).

A proposta de Rincon é voltada a descrição, de conto, que remonta o período escravocrata ao mesmo tempo em que cria um jogo com representações 


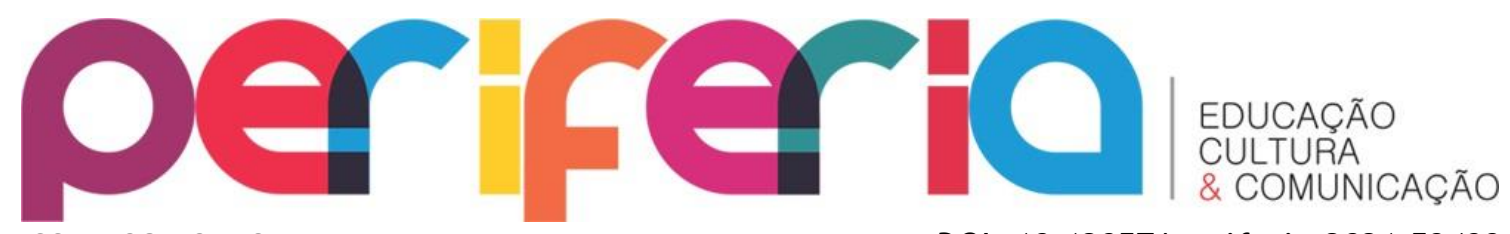

ISSN:1984-9540

DOI: 10.12957/periferia.2021.53499 atuais, tais como o negro que foge da polícia trajando trajes modernos (tênis e moletom) e o próprio policial, que é força de repressão maior a serviço do Estado, mas é visto também como metáfora da figura repressora dos tempos coloniais.

Em entrevista concedida ao site RedBull (2018), o cantor afirma que "Crime Bárbaro" atua como alegoria da violência e do genocídio que acomete negros no país, no qual o racismo institucional atua em função dos resquícios da escravidão mesmo após sua abolição oficial em 1888.

Figura 1 - Rincon Sapiência: Crime Bárbaro (2018)

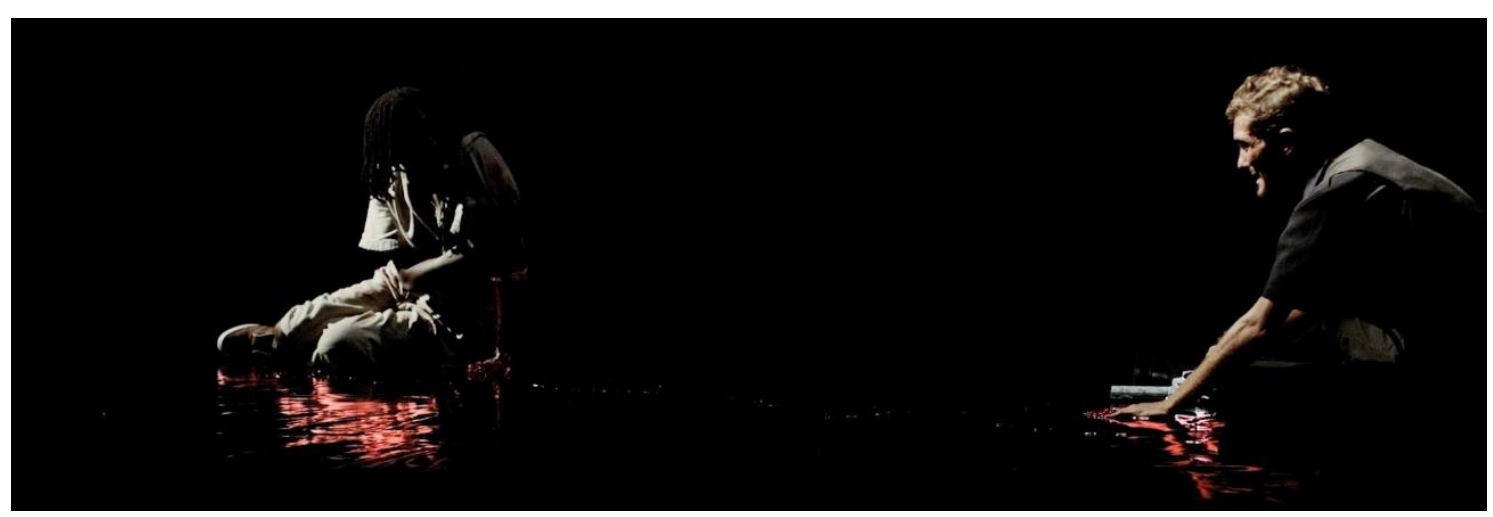

Fonte: Uol Entretenimento, 2018.

$\mathrm{O}$ ato de fuga, por parte de Galanga, é apontado em diversos momentos da construção da narrativa. Nos quase quatro minutos de vídeo, Rincon foge incansavelmente do policial que permanece em seu encalço, portando os mais diversos tipos de arma de fogo. Frases como: "Nossa senhora, neguinho passou a mil", "Canela fina é pra correr", "Corre nego fujão" e "Boatos correm e eu também", embalam o cancioneiro e levam o espectador a torcer pelo narrador, que mesmo alegando ter matado o senhor de engenho, tem consigo alegações sobre o porquê de tal ato.

Meu crime a ele eu culpo Bateu em criança, cometeu estupro

Proibiu a dança e a religião Gerou confusão interna entre o grupo

Cana-de-açúcar e sol quente Rachando na cuca, ódio na mente Lembro do seu braço preso no meu dente (Ah!) Depois não foi um acidente 


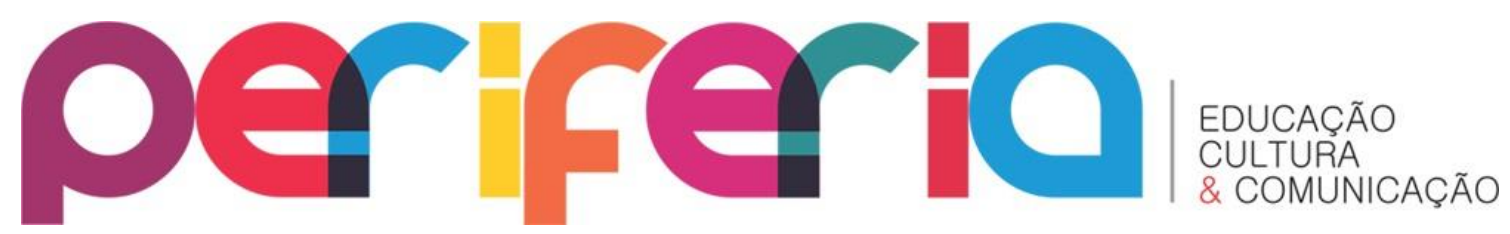

ISSN:1984-9540

DOI: $10.12957 /$ periferia.2021.53499

Preso e vivo, morto e liberto

Logo pensei, um dia te acerto

(Ah!) Ele diz "esse nego é o cão". (RINCON SAPIÊNCIA - Crime Bárbaro, 2018).

Galanga, no entanto, afirma estar sem esperanças de continuar vivo, uma vez que tem em mente a perseguição por parte daqueles que "querem sua cabeça na ponta da lança" que se findará quando for capturado e consequentemente morto. 0 videoclipe é finalizado com Galanga e o seu captor em uma piscina de sangue do escravo fugitivo, o que marca a narrativa com um aspecto desolador, e atua de forma destoante na construção imagética de um escravo que chegou a seus limites para conquistar sua liberdade.

Jovens cantores do rap brasileiro como Rincon Sapiência e Djonga exaltam a construção de uma memória ancestral, que ajuda os jovens negros a compreenderem suas matrizes originárias e as correlações existentes entre elas e sua realidade cotidiana. Galanga é representado como escravo, mas também como um homem comum, tendo em vista suas vestes ao início do clipe; ao removê-las alterna entre o homem negro atual e o escravo de vestes simples, enquanto que o policial ora alterna como a figura do capitão do mato, ora como a repressão cotidiana configurada pelas armas de fogo que buscam acertar o alvo, que no caso retratado é um corpo negro.

As correlações propostas por Djonga, a partir da canção "Corra", remontam também o pensamento ancestral, visto a realidade atualizada do negro que busca compreender seu lugar no mundo. Com título homônimo a obra Corra! (Get Out de Jordan Peele 2017) ${ }^{7}$, a canção inicia-se com a declamação em suaíli dos versos de Sikiliza Kwa Wahenga, que compõe a trilha sonora do filme e pode ser lida em português como "Irmão, fuja! Ouça mais seus ancestrais".

\footnotetext{
7 . Com lançamento em 2017, "Corra" (Get Out), retrata a história de Chris, um jovem negro que está prestes a conhecer a família de sua namorada, a caucasiana Rose. A princípio, ele acredita que o comportamento excessivamente amoroso por parte da família dela é uma tentativa de lidar com o relacionamento de Rose com um rapaz de sua etnia, mas, com o tempo, ele percebe que a família esconde algo muito mais perturbador. (Fonte: Adoro Cinema, 2017.)
} 


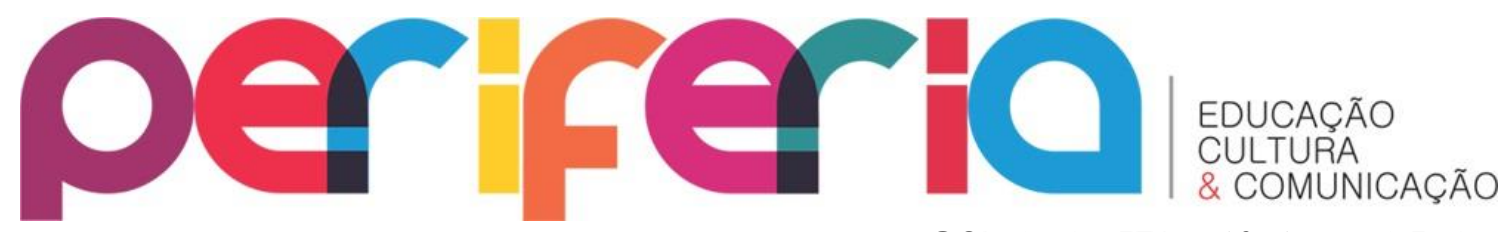

ISSN:1984-9540

DOI: $10.12957 /$ periferia. 2021.53499

Em um cenário de pouca luz, o rapper corre também no escuro como se fugisse em direção ao espectador, até que é iluminado por um telão onde são apresentadas imagens de seus olhos perdidos, que alternam com imagens históricas, como a ascensão do nazismo. Ora perdido dentro do telão, ora perdido frente a ele, o cantor inicia seus versos como em uma carta para a mulher amada.

Amor, olha o que fizeram com nosso povo Amor, esse é o sangue da nossa gente Amor, olha a revolta do nosso povo

Eu vou, juro que hoje eu vou ser diferente (Djonga feat Paige - Corra, 2018).

Figura 2 - Djonga feat Paige - Corra, 2018

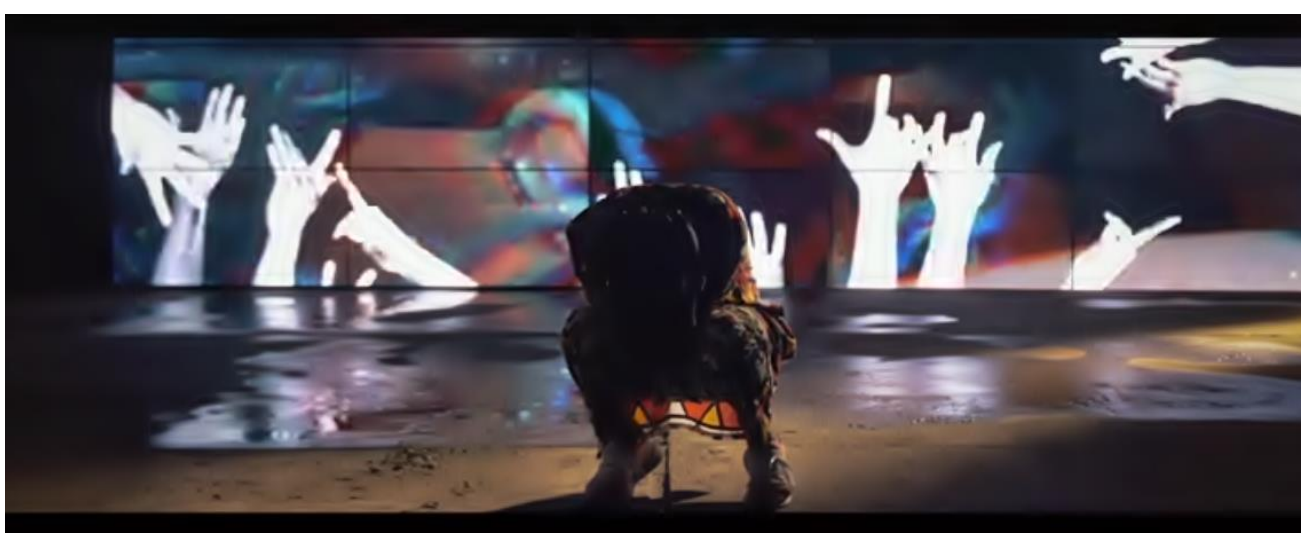

Fonte: Polifonia Periférica, 2018.

A participação da cantora Paige atua como ponte melódica da narrativa grave de Djonga, que aponta a desolação do homem negro, ao figurar-se sem lugar, uma vez que se vê diante dos aspectos da branquitude desde a escravidão.

Eles são a resposta pra fome Eles são o revólver que aponta Vocês são a resposta porque tanto Einstein no morro morre e não desponta Vocês são o meu medo na noite Vocês são mentira bem contada Vocês são a porra do sistema que vê mãe sofrendo e faz virar piada, porra Eu vi os menor pegando em arma, pois cês foram silenciadores

Eu vi meu pai chorando o desemprego, desespero Pra que isso, mano? 


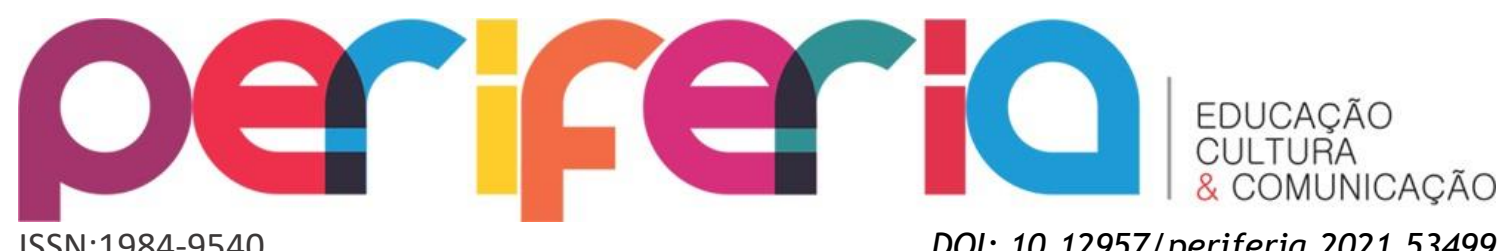

Eu não quero vida de pizzaiolo, e sim ser dono da pizzaria Querem que eu me contente com nada

Sem meu povo o tudo não existiria

Eu disse: "Óh como cê chega na minha terra" Ele responde: "Quem disse que a terra é sua?".

(Djonga feat Paige - Corra, 2018).

Aspectos marcantes como a perda da autoestima do jovem negro e a entrada para a criminalidade são apontados, durante a construção da canção. No entanto, ela é carregada pela promessa de novos tempos, que segundo o cantor configuram a retomada de seu mundo. A construção do videoclipe culmina com o seu apagamento, da frente do telão e a consequente sequência de disparos de arma de fogo. O telão é novamente iluminado, trazendo consigo o nome e a data do assassinato de negros no Brasil em consequência de balas perdidas ou confrontos policiais.

O apagamento de Galanga e Djonga pode ser lido pela dualidade entre a retomada da autoestima e sua destruição, reflexos da cultura supremacista branca que observa a retomada da autoestima negra, bem como do amor à negritude como um crime que abala de formas tão profundas a tessitura social que deve ser punida com a morte (hooks, 2019).

Os aspectos relacionados ao ato de correr dentro das narrativas anteriormente analisadas levam o indivíduo à morte, atuando como uma fuga ineficaz, pois mesmo mobilizando aspectos sensíveis para a luta negra, estas invariavelmente recaem na extinção do sujeito que busca tornar-se parte do visível frente ao apagamento socialmente estabelecido por meio da violência.

Portanto, qual seria a saída possível para que outras representações do jovem negro venham à tona no quadro das reproduções midiáticas? Para hooks (2019), a mudança das representações deve estar aliada a transformação do olhar, principalmente quando o foco é voltado para pessoas negras pelos signos que compõem a negritude, sendo somente através do amor pela negritude possível romper com as barreiras de negação e auto-ódio que lançam as vidas negras à morte. Conforme apontado por Malcolm X, citado por hooks (2019), temos que mudar nossas mentes (...) temos que mudar nossos pensamentos a respeito uns dos outros. Temos que nos ver com novos olhos. Temos que nos aproximar de modo caloroso. 


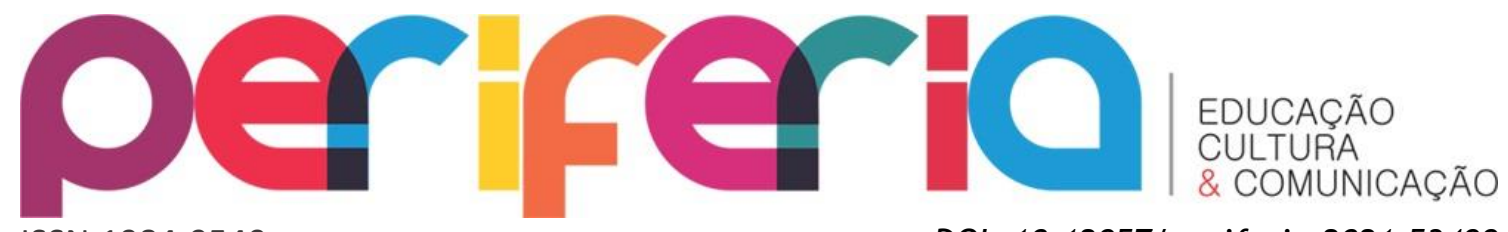

ISSN:1984-9540

DOI: $10.12957 /$ periferia.2021.53499

É a partir da análise de "Bluesman" (2019) que se torna possível observar as relações instituídas entre o negro que corre e a construção do aspecto de resistência para além da demarcação do corpo negro, enquanto alvo para a violência. Com título homônimo ao álbum lançado por Baco Exu do Blues. 0 curta foi ganhador do prêmio Grand Prix na categoria Entertainment for Music do Cannes Lion 20198. Com 8 minutos de duração, "Bluesman" narra as relações instituídas entre negros no país e promove a discussão do racismo enraizado na sociedade brasileira.

Protagonizado por Kelson Succi e com a participação de Hilton Cobra, o filme leva o espectador a considerar o personagem principal como um bandido logo em seus primeiros frames. A causa para tal preconceito? 0 negro corre.

Figura 3 - Bluesman Filme - 2019

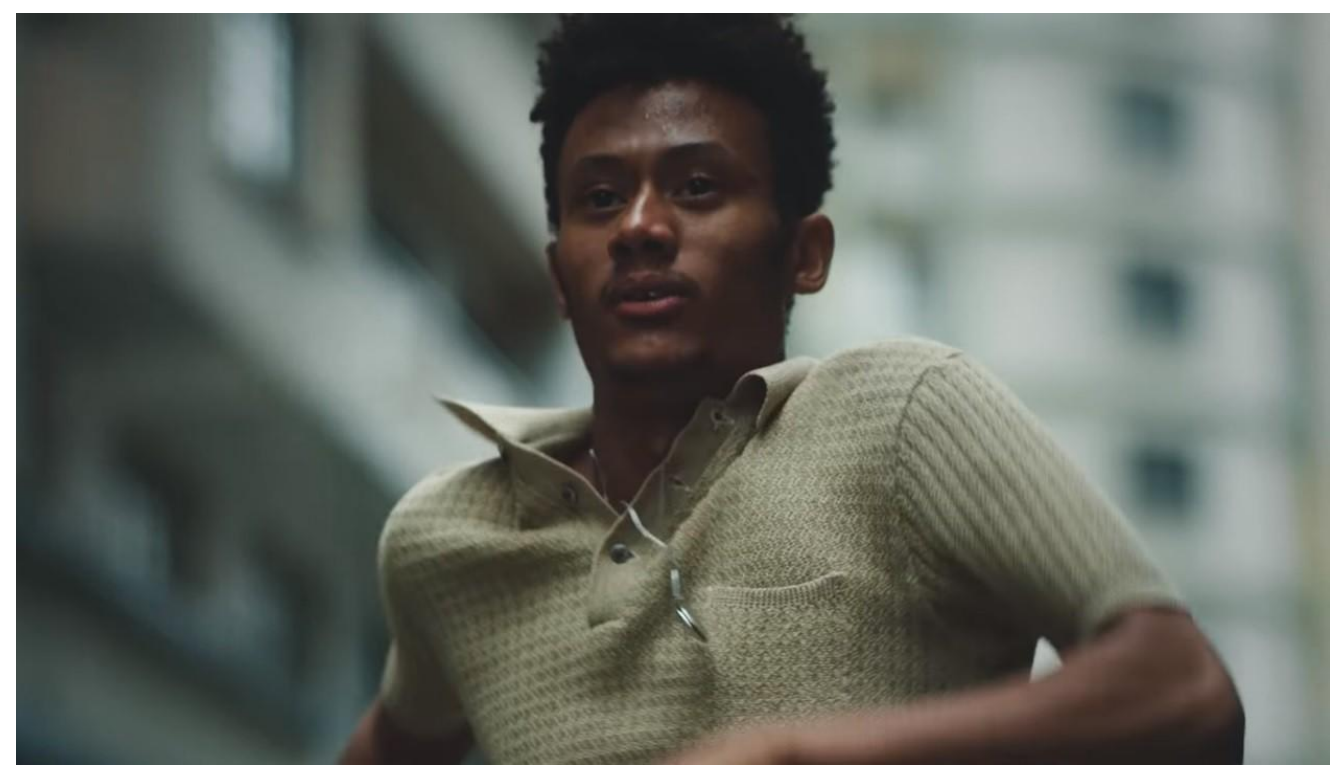

Fonte: O Globo, 2019.

Em meio a um cenário caótico, no qual vemos o personagem principal atravessar a névoa e em meio às batidas que compõem o álbum, somos apresentadas a trechos das canções que sobrepõem a corrida do personagem

8. G1. Clipe de Baco Exu do Blues ganha prêmio no festival de publicidade de Cannes: 'Bluesman' conquistou o Grand Prix - premiação máxima - na categoria "Entertainment for Music" do Cannes Lions.. G1, [S. l.], p. 1-1, 19 jun. 2019. Disponível em: https://g1.globo.com/economia/midia-e-marketing/noticia/2019/06/19/clipe-de-baco-exudo-blues-ganha-premio-no-festival-de-publicidade-de-cannes.ghtml. Acesso em: 6 jan. 2020. 


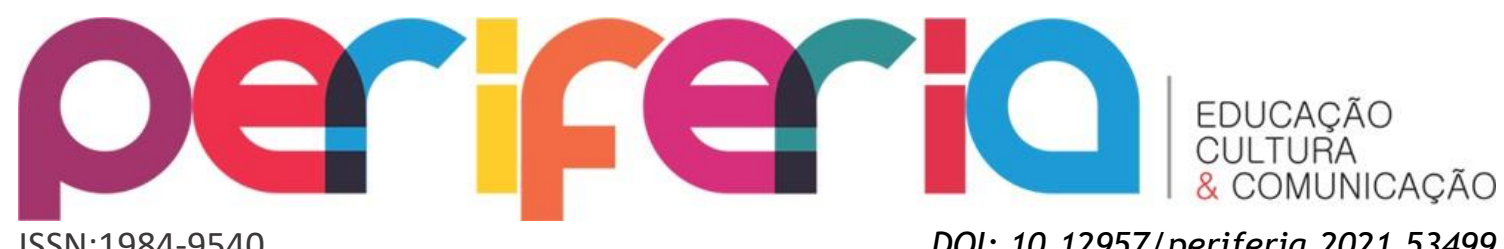

ISSN:1984-9540

DOI: 10.12957/periferia.2021.53499

principal. Baco inicia seu discurso, a partir do encontro do jovem que corre com um idoso em um campo de trigo:

Eu sou o primeiro ritmo a formar pretos ricos

0 primeiro ritmo que tornou pretos livres Anel no dedo em cada um dos cinco Vento na minha cara, eu me sinto vivo A partir de agora considero tudo blues 0 samba é blues, o rock é blues, o jazz é blues O funk é blues, o soul é blues, eu sou Exu do Blues

Tudo que quando era preto era do demônio E depois virou branco e foi aceito, eu vou chamar de blues

É isso, entenda Jesus é blues Falei mermo.

(Baco Exu do Blues - BLUESMAN, 2019).

Baco afirma que seu ritmo foi o pioneiro frente à libertação dos negros, quando relaciona seu ritmo ao blues, que caracteriza um gênero formado por escravos afro-americanos no final do século XIX, e que gradativamente foi sendo inserido nas músicas brancas estadunidenses. A correlação com o samba brasileiro também pode ser compreendida através do viés de suas origens históricas, enquanto uma expressão do grupo de negros marginalizados que buscavam afirmar os aspectos de sua etnia no quadro da vida urbana brasileira. Portanto, onde estava o negro estava o samba, como uma demonstração de resistência ao imperativo social escravagista que buscava reduzir o corpo negro social e a cultura africana somente a uma máquina produtiva. 0 samba que deveria ficar ao fundo das senzalas e quintais só passa a ser socialmente aceito em 1923, quando obteve o "direito" de penetrar no espaço urbano branco através dos desfiles das escolas de samba (SODRÉ, 1979).

A produção de Baco também conta com a afirmação do amor à negritude, por meio da narrativa de Milton Coimbra sobre os aspectos valorativos que ligam a pele negra à prata.

A prata é um metal com poder de reflexão muito elevado. Do latim argentum, significa brilhante. Nossa pele é de prata. Ela reflete luz. Um brilho tão intenso que eu the pergunto: 'por que o ouro é tão querido, e a prata subvalorizada?' Alguns vão dizer que é porque a prata é encontrada com mais facilidade. 


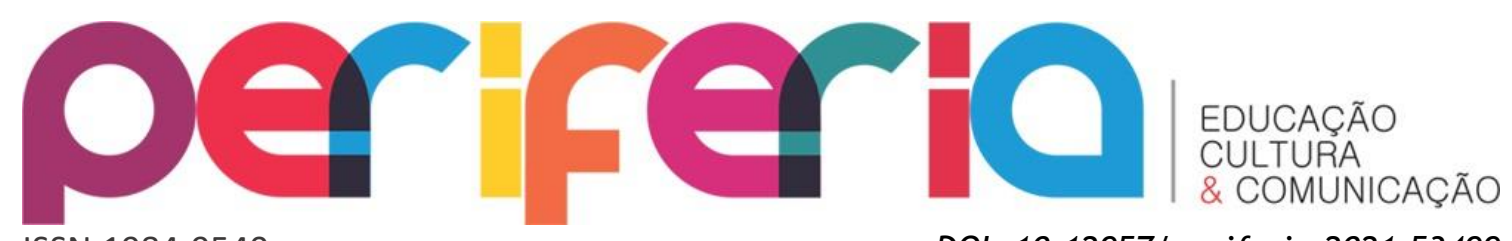

Reflita.

O Brasil tem uma população de negros maior que a de brancos.

Temos menos valor por ser maioria?

A ironia da maioria virar minoria. A prata é um metal puro.

Eu realmente não entendo essa necessidade da procura do ouro. (Baco Exu do Blues - BLUESMAN, 2019).

Correlações entre a prata e a pele evocam a crítica às políticas de embranquecimento que figuraram no século XIX, a partir das teorias propostas pelo darwinismo racial que buscavam apagar o passado negro do país, através da esterilização de afrodescendentes. 0 que parece ser parte das marcas do passado de nosso país é ainda presente, uma vez que em 1982 o Grupo de Assessoria e Participação do Governo do Estado de São Paulo (GAP) propunha, em relatório, a esterilização de mulheres pretas e pardas, sob o argumento de que as projeções demográficas demonstravam crescimento da população escura e que isso resultaria na ocupação do poder político por afrodescendentes (SODRÉ, 1999).

Narrar sobre a valorização da negritude é um dos eixos que torna "Bluesman" tão interessante, vide exemplo do corte executado entre o ato de correr e sua sobreposição por negros, que ocupam a mesa com trajes que até então só eram utilizados pela burguesia escravocrata, permitindo uma mudança paradigmática do belo. 


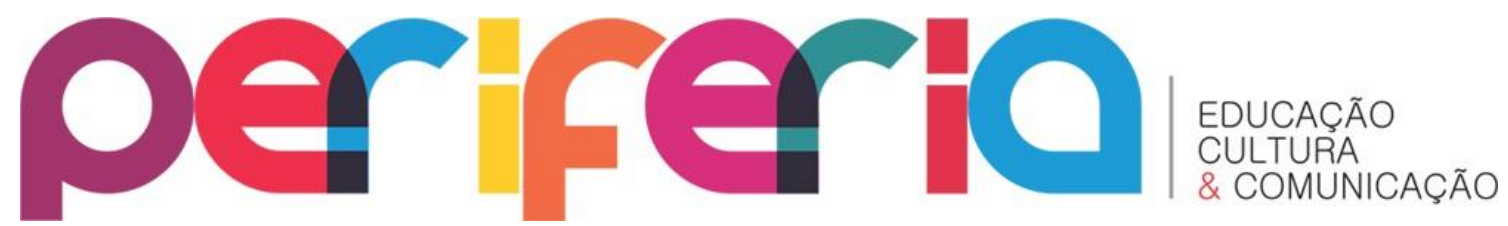

ISSN:1984-9540

DOI: $10.12957 /$ periferia.2021.53499

Figura 3 - Bluesman Filme - 2019

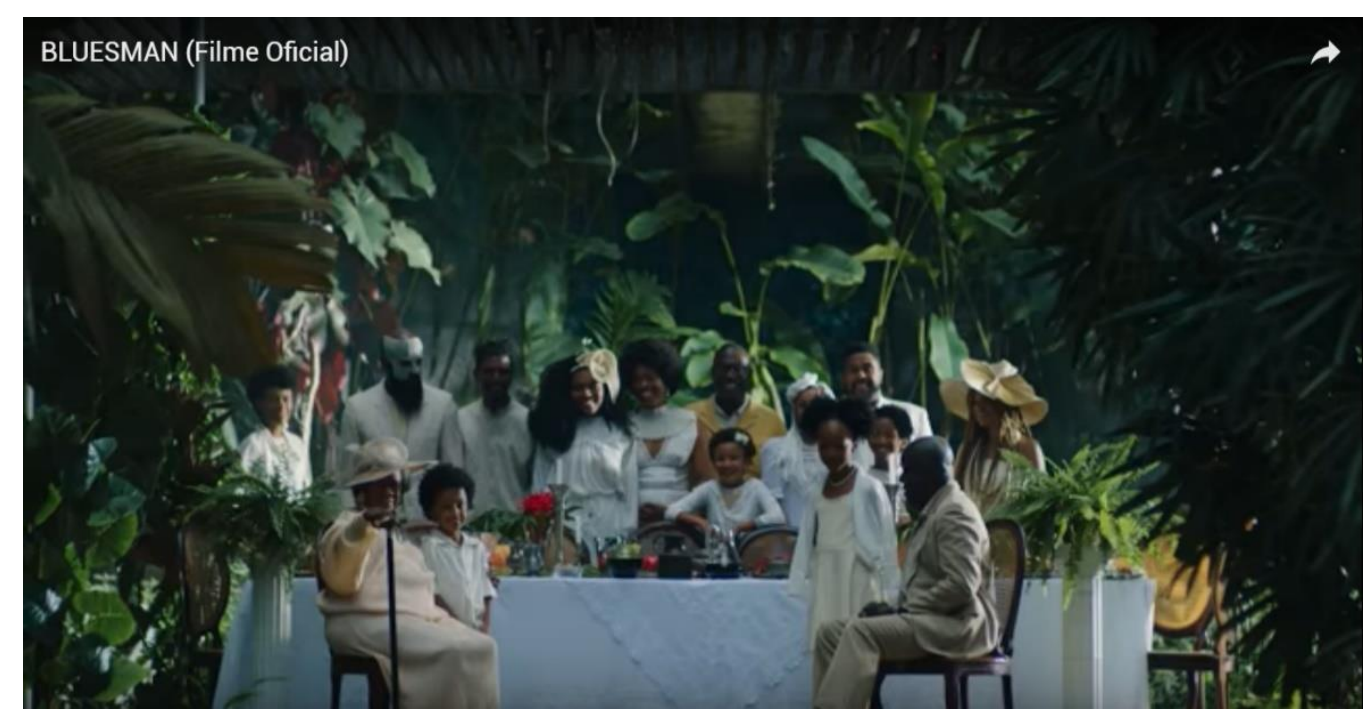

Fonte: 999, 2018.

Ao afirmar "eles querem um negro com a arma pra cima num clipe na favela gritando: Cocaína" ou que "querem que nossa pele seja pele do crime", Baco afirma-se ciente do local almejado para as representações de negros e negras. Entretanto é categórico ao afirmar que não planeja se ater às representações como a única realidade possível para sua arte, bem como para os seus semelhantes.

0 personagem principal que corre é também recebido em um terreiro e sua entrada neste local é coroada com as batidas de tambor que compõem a canção Minotauro de Borges:

Negro correndo da polícia com tênis caro Tipo Usain Bolt de Puma não paro Correndo mais que os carros Eu não fui feito do barro

Pisando no céu enquanto eles se perguntam Como esse negro não cai?/ Dizem que o céu é o limite

Eles se perguntam

Porque esse negro não cai? (...) Depois que eu morri com um tiro na cabeça Sempre que um preto faz dinheiro grita BACO VIVE, BACO VIVE (...) Museus estão à procura de mármore negro Pra fazer uma estátua minha. (Baco Exu do Blues - BLUESMAN, 2019). 


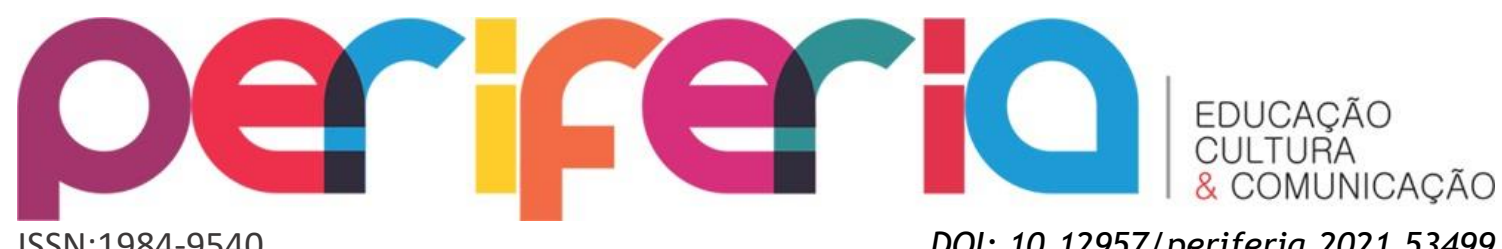

ISSN:1984-9540

DOI: $10.12957 /$ periferia.2021.53499

A música, por sua vez, tensiona conceitos opostos, como o ato de correr e a força repressora do aparato policial, bem como a negação de sua figura e o barro. Ao fazê-lo, Baco se alça como deus e mesmo morto é saudado em vida: por negros que como ele alcançam de alguma forma o sucesso.

Ao colocar tais elementos conectados com o filme-conceito de seu álbum, o cantor demonstra que sua ancestralidade não deverá mais ser vista de forma segregada, uma vez que também é sagrada.

“Bluesman” perpassa diversos elementos entre a correria do jovem negro e o frequente desconforto causado ao espectador, que espera o desfecho para a correria, concretizada quando o personagem principal chega a sua aula de música e justifica ao professor que corria por estar atrasado.

\section{Considerações Finais: sobre o negro que corre, fronteiras e frestas}

No filme “Bróder” (2010), de Jeferson De, em determinado momento da trama, Francisco (Ailton Graça) faz um gesto a Macu (Caio Blat), reconhecendo os percalços que o afilhado vem enfrentando nas negociações e nos pactos firmados com os códigos de violência da periferia do extremo sul da cidade de São Paulo, mais especificamente o bairro de Capão Redondo. Francisco quer “presentear" o afilhado com uma arma de fogo, para que Macu a utilize como objeto de proteção, diante das investidas de um mal exterior, dos agentes da contravenção e do pequeno tráfico local. Macu não só não aceita o presente como assevera ao padrasto uma frase emblema, presente no seguinte diálogo: “Francisco: - pega essa arma, bróder; Macu: - não é bróder, é mano!” A síntese retórica do linguajar carioca de Francisco, e de um lugar identitário autorreconhecido, parece permear a produção do hip hop brasileiro a partir do final dos anos 1980: na distinção, não só geográfica entre São Paulo e Rio de Janeiro, mas principalmente na proeminência da expressão mano como sentido de autoconsciência periférica. Isso se dá também na decorrência das influencias do rap norte-americano, mais marcadamente em artistas e grupos como Public Enemy, Run DMC e NWA. A utilização e a escalada do termo mano, em contraposição à irmandade de broder, adquire um sentido de comunhão 


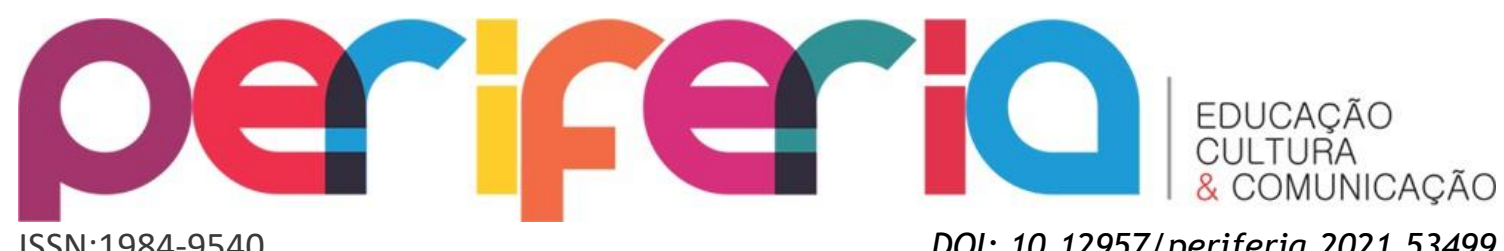

particular, espreitado a partir de um sujeito periférico também internacional.

Em “Bróder”, na parceria e no encontro de Macu com os amigos de infância do Capão: o agora jogador de futebol Jaiminho (Jonathan Haagensen) e o “certinho” Pibe (Silvio Guindane). É com eles que Macu terá de fazer a correria.

A geração de Baco Exu do Blues, Djonga e Rincón Sapiência se traveste, ainda, portanto, da indumentária de uma gênese estética, e reivindica também a possibilidade de outras aberturas; de frestas, que estão delimitadas, justamente, no espírito comunitário que a expressão mano carrega e insinua. A consequente correria atribuída a essa entidade urbana é reinterpretada, então, à luz de referências comunitárias e na propositura, vamos assim dizer, de uma embalagem estética, em que o corpo periférico se imbui de urgência, no campo da arte musical, em duas frentes de sentido, pelo menos: a) a ancestralidade da diáspora negra incorporada às vivências cotidianas do jovem periférico contemporâneo, b) a denúncia da prática racista a qual esses atores estão envolvidos na lida diária.

A título de comparação, o filme “Corra!” (Get Out, 2017), de Jordan Peele, dialoga com as descrições aqui destacadas, já que Chris (Daniel Kaluuya) se vê envolto numa trama aterrorizante, em que participantes de uma sociedade elitizada, branca e "culta” (falsamente progressista) preenchem e prendem o corpo negro (e simbólico) de Chris, numa espécie de redoma asfixiante, utilizando-se das mesmas engrenagens do processo de escravização de pessoas negras no século XIX, no continente americano, ao sul e ao norte. Resta a Chris, com a ajuda externa do amigo Rod, por meio do dispositivo do telefone celular, fazer a renúncia do estado de coisas a que foi submetido (o amor inter-racial com a jovem Rose, a assimilação cordial com a família de outro estrato social), em que a tensão racial se institui como procedimento a ser tomado e como demanda para o salto de uma autonomia que lide com os traumas e fantasmas do passado. No caso, Chris precisa se livrar da ofensiva e da vilania da família de brancos, especialmente da namorada Rose, assim como se virar em meio a uma particular correria. Para Wellington dos Santos, “Corra!" estabelece, com suas alegorias políticas, uma depuração das 


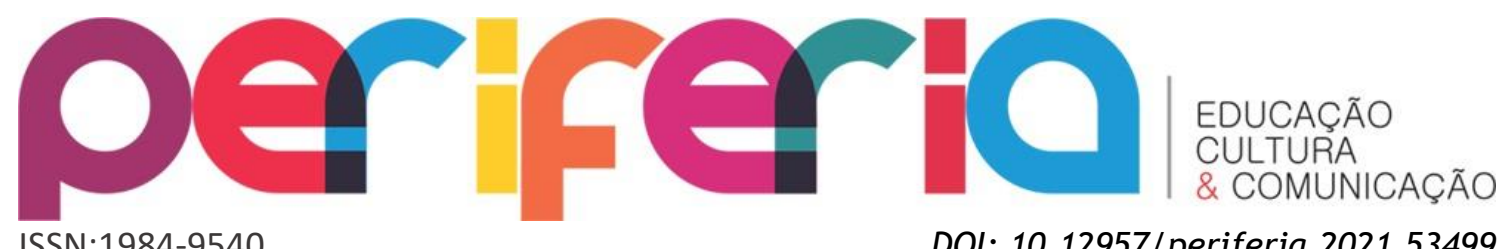

representações identitárias no cinema quando alinhava a reviravolta catártica ao final:

Pode-se dizer que a identidade de Chris, enquanto processo [...] chega ao final da narrativa diferente do modo como começou. Ele sai de uma situação de extrema passividade diante do mundo dos brancos para construir sua liberdade, seja do passado que o escraviza (suas memórias para com sua mãe), seja dos opressores do presente (SANTOS, 2018, p.289).

Percebe-se com o movimento de personagens como Chris e Macu (cada um com suas questões pessoais específicas) que a correria é um emblema revisitado para um ato político de autonomia racial, semelhante em grande medida à expressividade artística de Baco Exu do Blues, Djonga e Rincón Sapiência. No cinema de Jeferson De e de Jordan Peele, isso parece lógico e razoável: há um questionamento da longa tradição do gênero cinematográfico americano, estabelecido em representações preconcebidas a respeito das práticas sociais exercidas (e dos deslocamentos espaços-temporais definidos pelo cinema clássico, cuja principal ordem melodramático-representacional talvez seja a mão racista de "O nascimento de uma nação" (The Birth of a Nation, 1915). Spike Lee com, principalmente "Faça a coisa certa" (Do the real thing, 1989) e A hora do show (Bamboozled, 2000), parece ter dado a pista do novo jogo da representação, especialmente a racial, na inversão das proposições tipológicas sociais de personagens afro-americanos. O corpo negro, desde então, nesta filmografia e nesta iconografia mais recente, está disposto em várias atribuições, na apreensão crítica da própria indústria dos espetáculos, em forma e conteúdo temático, como, por exemplo: a) a incorporação da postura gangsta como marco identitário da performance juvenil dos guetos, b) o uso das acepções nigga e bitch como atributo positivo, ou não depreciativo simplesmente, a depender da subjetivação, c) a batida rítmica dos raps se aproximarem da batida rítmica dos filmes, quase como uma sintonia poética, d) a edificação de uma ideia de conhecimento baseada na e sobre as "quebradas".

Trata-se de marcas decisivas para a construção simbólica do rap no novo milênio. Elas estão ancoradas, e continuam a reforçar, no emblema das 


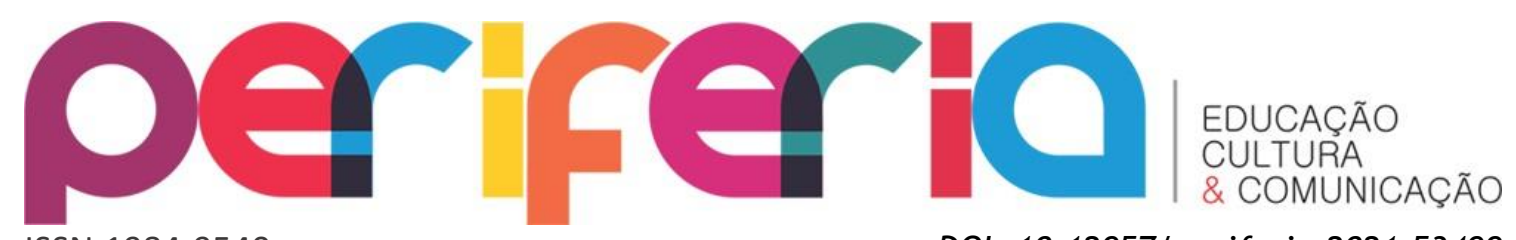

ISSN:1984-9540

DOI: $10.12957 /$ periferia.2021.53499 correrias, no canto utópico materializado nos filmes acima mencionados. Em entrevista ao programa Sangue latino, o escritor e jornalista uruguaio Eduardo Galeano resume a ideia da utopia como o inalcançável: “você caminha e a utopia está no horizonte, você caminha mais um pouco e a utopia também se distancia no horizonte. Pra que serve a utopia? Para isso, para caminhar".

Pois bem. Os trabalhos audiovisuais aqui examinados de Baco Exu do Blues, Djonga e Rincón Sapiência se investem do semblante utópico e do atributo próprio da estética do hip-hop contemporâneo, em múltiplos jogos de referências, a corroer o significado de representações ancestralmente marcadas pela indústria cultural. Em larga medida, trata-se de um novo argumento para o sentimento utópico, nos termos de Galeano. Desse modo, a temática da correria assume um valor que sintetiza a produção dos artistas, em diálogo íntimo com a guinada estética valorizada pelo pela denúncia dos processos de pilhagem dos "corpos e almas", que continuam envolvidos em torno da morte desse mesmo escopo social e racial: no trânsito do capital, no trânsito das fronteiras dos países e no trânsito das fronteiras das cidades e comunidades.

É curioso notar o trânsito (em complemento à noção de correria), se pensarmos no que salienta Mbembe, quando traduz o sentimento diaspórico africano na descrição dos movimentos e deslocamentos dos negros no mundo globalizado e suas respectivas aflições: "O aprisionamento se tornou a precondição para a exploração do nosso trabalho, e por isso as lutas pela emancipação racial e por melhoria das condições de vida dos negros são tão entrelaçadas às lutas pelo direito de circular livremente" [grifo nosso] (MBEMBE, 2019, p.79).

0 que Mbembe resume, neste texto especificamente, quando fala da permeabilidade das fronteiras e dos fluxos contemporâneos, é o jogo das distinções, e a quem cabe ou é reservado o direito de viver (ou morrer) nesta diáspora negra contemporânea. Nesse sentido, os três vídeos aqui examinados, de três artistas brasileiros jovens contemporâneos, ditam uma materialidade (complementada em forma metalinguística em Corra!, e em crônica do mundo periférico em Bróder) do negro prestes a: a) escapar da truculência do controle 


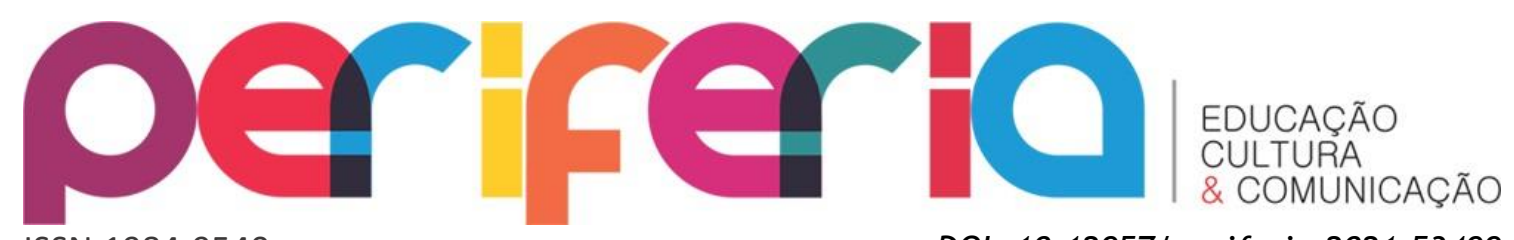

ISSN:1984-9540

DOI: $10.12957 /$ periferia.2021.53499

sobre seus corpos, b) expiar a possibilidade de uma nova redenção, c) transcender o processo ancestral de escravização.

Uma ideia clássica da utopia é empreendida para esses objetivos dos artistas, na fundamentação teórica de Mbembe, e não seria exagero dizer que tal geração internacionalizada e educada a uma atividade artística fim (afinal de contas, "periferia é periferia em qualquer lugar", como vaticinavam os Racionais Mc's, em 1997, na música “Periferia é periferia”) anuncia um discurso singular sobre a esperança, considerando narrativas envolvendo marcas internacionalizadas e reinventando, paradoxalmente, as experiências locais. Isso acontece em Rincón Sapiência, nas possibilidades de danças ancestrais encenadas no pop universal; com Djonga, na reinvenção do flow característico da batida do rap, testando os limites da agressividade poética; com Baco Exu do Blues, na experimentação do crossover musical e poético. Nos três, as inumeráveis referências eruditas mobilizadas estão a serviço na função da fresta, da abertura, da possibilidade, e do insumo da correria como ganho estético e político.

Estamos diante, portanto, de potencialidades que reconfiguram a tradição de sujeitos da correria ancestral, essa que pode ser vista na compreensão feita pelas expressões triunfantes do rap nacional: o vida loka e o preto zica - tematizados simbolicamente pelos Racionais, respectivamente nos álbuns Nada como um dia após o outro dia (2002) e Cores e valores (2014)), mas também refletidos em BK, na música "Correria", e em FEBEM, no álbum "Running": uma espécie de apanhado metodológico sobre a modalidade das correrias, ontem e hoje.

A análise por nós proposta pretendeu-se, no mais, alinhavar principalmente dois pensadores em um mesmo escopo de discussão sobre os encontros internacionalizados - hooks e Mbembe - como também articular a produção audiovisual de três artistas por meio das intensas acumulações, assimilações e incorporações gestadas por esse pensamento sobre a cultura contemporânea.

Há, com isso, tanto uma espécie de linha evolutiva de uma produção entendida como música preta internacional, como a enunciação das 


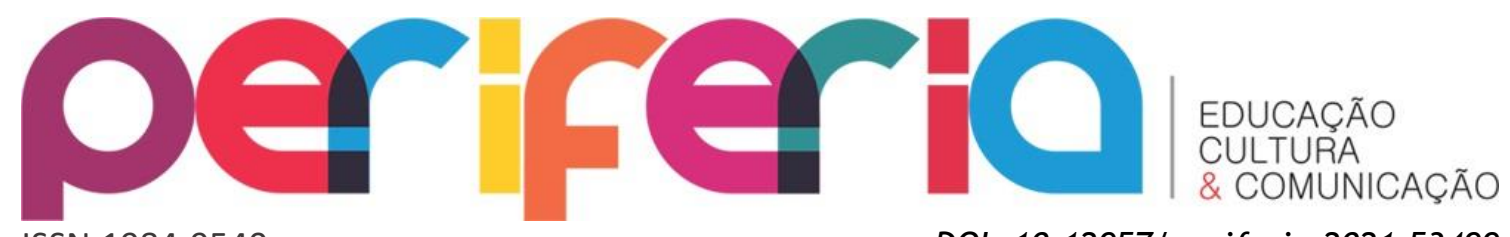

ISSN:1984-9540

DOI: $10.12957 /$ periferia.2021.53499 especificidades da produção marcada por respectivas caracterizações regionais: Djonga (MG), Baco (BA) e Rincón (SP). Tais marcos fronteiriços e suas limitações resumem o processo de assimilação das subjetividades como algo que está fortemente anteposto no rap dos Racionais Mc's, em "Da ponte pra cá": "não adianta querer, tem que ser, tem que pá, o mundo é diferente da ponte pra cá, não adianta querer ser, tem que ter pra trocar, o mundo é diferente da ponte pra cá".

A rotina da correria implica o entendimento daquilo que é referenciação dos guetos, cafuas, santuários, vilas, dos pequenos espaços carcomidos das cidades e dos lugares de vivência-limite, especialmente estes que estão dispostos nas regiões-fronteiriças da urbe incorporada ao jogo do capital global internacionalizado. O termo gueto estampa o mano de Bróder e o mano de “Corra!", em uma tensão associada à ideia de comunhão, este paradoxo que Francisco tenta empreender em Bróder, quando tenta por em xeque o impasse da correria de Macu e sua possibilidade de rompimento com a violência.

Além disso, a correria estabelece limites, como em "Da ponte pra cá", e prevê que determinadas trevas e luzes estão na linha de frente de limitações e fronteiras. Tais imagens reinventam a autorreflexão dos atores periféricos: jovens em percalço, em périplo de provação recorrente, a reafirmarem pela dança anticelebrativa, no fim das contas, resumida talvez pelo rap "Mandume”, de Emicida, no verso: “ao ver o Simonal que cês não vão foder”.

É por meio dessa linhagem, que é também ruptura, que o corpo se encanta em meio ao processo da percepção e da urgência da consolidação de uma nova correria; a beleza da evidência estética é também a constatação do horror e da degradação política a que estão inseridos corpos, almas e mentes.

As narrativas propostas pelos três rappers citados neste artigo figuram entre o desejo de liberdade, frente à opressão cotidiana e os elementos que marginalizam a negritude quando pensados por um viés supremacista branco. Rincon Sapiência e Djonga, demonstram que o jovem negro que corre, busca alcançar de alguma forma a vida, mesmo tendo a morte como única certeza. Por sua vez, Baco Exu do Blues, expõe o próprio espectador aos aspectos relativos ao racismo estrutural ao exibir o negro que corre. 


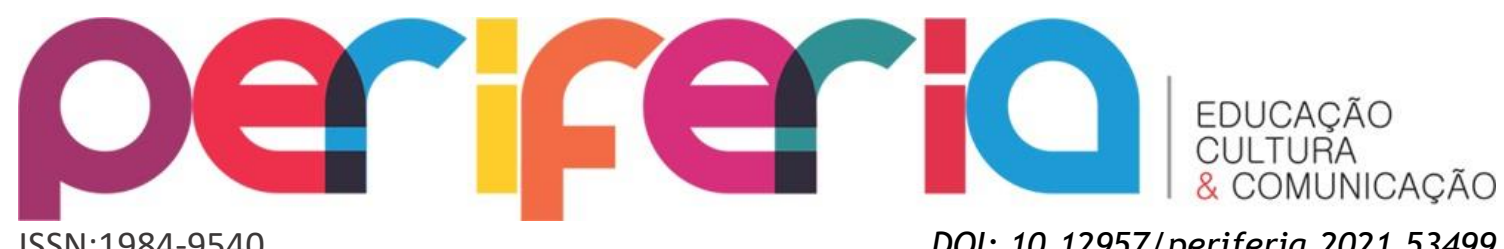

ISSN:1984-9540

DOI: $10.12957 /$ periferia.2021.53499

Os três videoclipes atuam como forma de demonstrar o racismo socialmente instaurado em nossa forma de olhar para corpos negros, que continuam a ser violentados mesmo após o período de abolição. Analisar o ato de correr nestes quesitos pode também ser lido como um ato de experiência estética, concebida segundo Moriceau e Mendonça (2016) como a experiência proveniente de um momento singular que repleta de significado é dotada da promessa de descobrir ou compreender algo, uma vez que cessa nossos movimentos e nos impulsiona a uma série de sensações e pensamentos. A correria, portanto, desponta não somente como efeito produzido por um corpo em fuga, mas como potencialidade dos corpos que buscam alcançar um ponto ainda invisível no horizonte do possível.

\section{Referências}

BLUESMAN. Direção: Douglas Ratzlaff Bernardt. Produção: Stink Films. Intérprete: Kelson Succi, Hilton Cobra. Roteiro: Baco Exu do Blues, Douglas Ratzlaff Bernardt, Christiano Vellutini, Lucas Andrade, Hugo Veiga, Diego Machado, Renato Zandoná, Paula Santana, Beatriz Durlo. Fotografia de Lucas Oliveira. Rio de Janeiro: [s. n.], 2018. Disponível em: https://www.youtube.com/watch?v=-xFz8zZo-Dw. Acesso em: 6 jan. 2020.

BORGES, Luiza Ribeiro. BRANQUITUDE E RELIGIÃO: A LUTA POR RESPEITO DAS RELIGIÕES DE MATRIZES AFRICANAS NO BRASIL. Rio de Janeiro: [s. n.], 2017. 71 p. Disponível em: https://www.maxwell.vrac.puc-rio.br/33218/33218.PDF. Acesso em: 5 jan. 2020.

BUZATTI, Lucas. Childish Gambino levanta debate sobre o racismo no clipe de 'This is America'. Hoje em Dia, [S. l.], 14 maio 2018. Disponível em: https://www.hojeemdia.com.br/almanaque/childish-gambino-levantadebate-sobre-o-racismo-no-clipe-de-this-is-america-1.620853. Acesso em: 6 jan. 2020.

CARMO, Beatriz. A pobreza no Brasil tem cor e é preta. Nexo, [S. l.], 18 nov. 2017. Disponível em: https://www.nexojornal.com.br/ensaio/2017/Apobreza-brasileira-tem-cor-e-é-preta. Acesso em: 6 jan. 2020.

DORNELAS, Luana. Trocamos uma ideia com Rincon Sapiência: Rapper falou sobre inspirações de seu último clipe "Crime Bárbaro". RedBull, [S. l.], 14 jun. 2018. Disponível em: https://www.redbull.com/br-pt/rincon-sapiencia-crimebarbaro. Acesso em: 6 jan. 2020. 


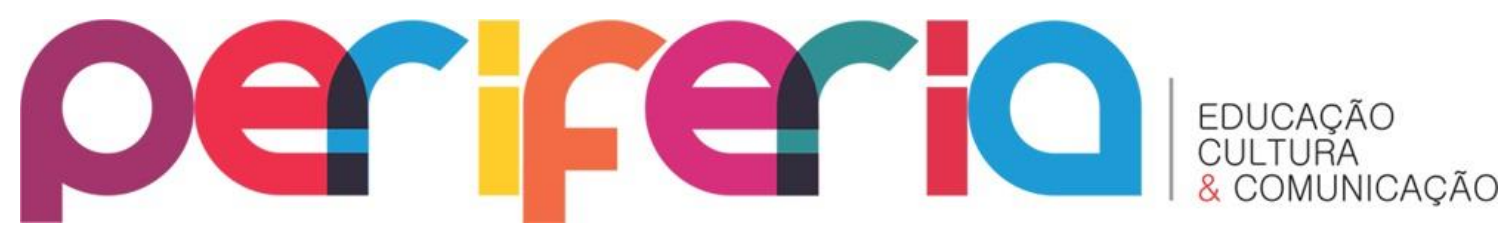

ISSN:1984-9540

DOI: $10.12957 /$ periferia.2021.53499

DJONGA feat Paige: Corra. Direção: Haruo Kaneko (Brwax ) e Rafael Carvalho. Produção: Studio Curva. Roteiro: Djonga. Fotografia de Haruo Kaneko e Igor Peticov. Brasil: [s. n.], 2018. Disponível em:

https://www.youtube.com/watch?v=QcJ9oxMj6Jl. Acesso em: 6 jan. 2020.

FRANÇA, Renan. Pesquisa americana indica que o Rio recebeu 2 milhões de escravos africanos. 0 globo, [S. l.], p. 1-2, 5 abr. 2015. Disponível em: https: / /oglobo.globo.com/rio/pesquisa-americana-indica-que-rio-recebeu-2milhoes-de-escravos-africanos-15784551. Acesso em: 6 jan. 2020.

HOOKS, Bell. Olhares Negros: Raça e representação/ Bell Hooks; tradução de Stephanie Borges. São Paulo: Elefante, 2019.

MBEMBE, Achille. A ideia de um mundo sem fronteiras. Tradução de Stephanie Borges. São Paulo; Rio de Janeiro: Revista Serrote, IMS, n.31, março 2019.

MICHAELIS, Dicionário. Dicionário Michaelis. [S. l.]: Melhoramentos, 2020. Disponível em: https: //michaelis.uol.com.br. Acesso em: 6 jan. 2020.

MORICEAU, Jean-Luc; MENDONÇA, Carlos Magno Camargo. Afetos e experiência estética: Uma abordagem possível. In: MENDONÇA, Carlos Magno Camargo et al. COMUNICAÇÃO E SENSIBILIDADE: Pistas Metodológicas. $1^{\mathrm{a}}$. ed. Belo Horizonte, MG: Selo Editorial PPGCOM, 2016. cap. 7, p. 78-98. Disponível em: https: / / seloppgcom.fafich.ufmg.br/novo/wpcontent/uploads/2019/08/Comunicação-e-Sensibilidade.pdf. Acesso em: 6 jan. 2020.

PUTTI, Alexandre. Assassinatos de jovens negros no Brasil aumentam $429 \%$ em 20 anos. Carta Capital, [S. l.], 17 abr. 2019. Disponível em: https://www.cartacapital.com.br/sociedade/assassinatos-de-jovens-negrosno-brasil-aumentam-429-em-20-anos/. Acesso em: 6 jan. 2020.

REIS, J. Quilombos e revoltas escravas no Brasil. Revista USP, n. 28, p. 14-39, 1 mar. 1996. Disponível em: www.revistas.usp.br/revusp/article/view/28362. Acesso em: 6 jan. 2020.

RINCON Sapiência - Crime Bárbaro. Intérprete: Rincon Sapiência. Brasil: Boia Fria Produções, 2018. Disponível em:

https://www.youtube.com/watch?v=RYYnpA-PQDk. Acesso em: 6 jan. 2020.

SANTOS, Wellington Oliveira dos. Corra! e as relações inter-raciais na diáspora: para uma discussão educacional. Niterói: Revista Mídia e Cotidiano, vol.12, n.3, dezembro 2018.

SODRÉ, Muniz. Samba, o dono do corpo. 1. ed. Rio de Janeiro: Codecri, 1979. (Coleção Alternativa). 


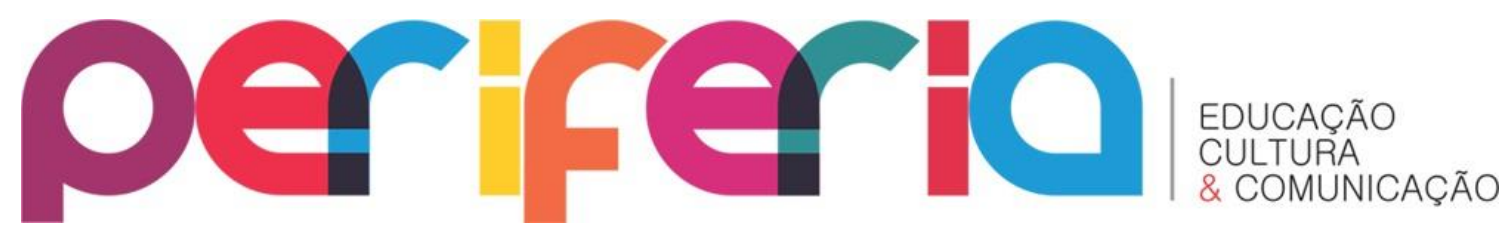

ISSN:1984-9540

DOI: 10.12957/periferia.2021.53499

SODRÉ, Muniz. Claros e escuros: identidade, povo e mídia no Brasil. 3. ed. Petrópolis: Vozes, 1999.

TEPERMAN, Ricardo. Se liga no som: as transformações do rap no Brasil. 1. ed. São Paulo: Claro Enigma, 2015. (Coleção Agenda brasileira). 